\title{
Biomass is a Promising Resource for Energy Generation
}

\author{
Márcia Silva de Jesus ${ }^{1 *}$, Angélica de Cássia Oliveira Carneiro ${ }^{1}$ and Clara Lisseth Mendoza Martínez ${ }^{2}$ \\ ${ }^{1}$ Department of Forest Sciences, Federal University of Viçosa, Brasil \\ ${ }^{2}$ Department of Federal University of Minas Gerais, Brazil
}

Submission: February 25, 2019; Published: March 20, 2019

*Corresponding author: Márcia Silva de Jesus, Department of Forest Sciences. Federal University of Viçosa, Viçosa, Brasil

\begin{abstract}
Energy is one of the main socioeconomic development inputs worldwide. It is estimated that in 2050, the global demand for energy and associated services will increase approximately 10 times [1]. The best alternative to reduce the use of non-renewable resources is to introduce the biomass as a source of renewable energy, which currently accounts for almost $14 \%$ of world consumption. To give you an idea, about 146 billion tons of biomass are produced per year. If $10 \%$ of this biomass - considering forest harvesting, wood and agricultural waste - is used to generate energy at $50 \%$ of efficiency, more than 3.1 trillion toe (tonne of oil equivalent), which represents a significant energy value [2].
\end{abstract}

Keywords: Socioeconomic; Biomass, Density; Humidity; Gaseous biofuels; Pyrolysis; Fermentation; Gasification; Soil Erosion; Air emissions; Biodiversity; Anthropic actions; Non-Renewable

\section{Mini Review}

In fact, the representativeness and importance of biomass in a country energy matrix, tends to increase as the national strategic policy focuses on the country's sustainable development. On the other hand, the main bioenergy producing countries are concentrated in the most developed regions of the world, represented by about $25 \%$, and in the remaining $75 \%$ describe the developing countries, which most of them still use biomass for primary subsistence: heat generation and cooking [3].

The problem of the developing regions is the absence of efficient biomass conversion technologies. In addition, sustainable management plans for the implementation of forests are insufficient. South America and Africa, for example, less than $30 \%$ of the areas are supported by sustainable energetic strategies [4]. Those projects are directly related to the high rates of deforestation in these regions.

Handling solid biomass (branches, animal carcasses, leaves, barks, among others) is not economical feasible for the purpose of generating energy. The concentration of energy is low and there is no regularity of physical properties such as dimension, density, humidity, stiffness, which are crucial factors for transportation, handling and storage [5]. One of the solutions found is the conversion of biomass into liquid and gaseous biofuels with higher energy density and more viable characteristics.
Nowadays, the biomass conversion routes can be divided into two categories: thermochemical processes (combustion, pyrolysis and gasification) and biochemical processes (fermentation, biodigestion, chemical and enzymatic hydrolysis). Faster production cycles presented in the thermochemical processes are preferred, although the economic behavior varies according to the integration and optimization of the system. In developing countries, operating costs become a major barrier to the implementation of these energy generation routes.

In Addition, there are Several Challenges Regarding the use of Biomass for Energy, such

a) economic return parameter, which depends on the applied technological level,

b) limited accessibility, which requires investments in transportation and may decrease its competitiveness in relation to other sources, especially when the biomass presents characteristics of heterogeneity and low energy density,

c) market price, which can be highlighted as a challenge, because often does not covertion costs. Likewise, increasing biomass consumption for energy may imply a

d) sharp use of natural resources, which means an intensive management practices in approximately $50 \%$ of the areas, would be used. A considerably high proportion, 
although there are still many uncertainties regarding the environmental impacts caused by this activity.

Among the environmental aspects, the challenges for the production of biofuels worldwide from biomass concern the reduction of greenhouse gases, since it is necessary to assess the life cycle of the region and the development of a standardized accounting methodology [6]. On the other hand, poor planning may cause soil erosion, water pollution, evaporative air emissions and possible loss of biodiversity [7].

Biomass is emerging as a promising resource for energy generation. However, the challenges associated with demand and conversion technologies need to be enlighten. Several studies report optimistic future scenarios adapted to available resources and process integration, nonetheless it does not mean that this scenario can be modified due to the anthropic actions of the present.

For this reason, a lot of investment in alternative sources of renewable energy, such as solar and wind, are taking place nowadays. After all, we have experienced, in practice, dependence on a single source of energy, especially non-renewable.

In fact, the introduction of new renewable sources into a country's energy matrix clearly demonstrates the economic, political and sustainable progress of a region. This leads us to understand that there is no doubt that biomass is one of the main development strategies along with the diversification of energy sources.

\section{References}

1. (2016) International Energy Agency, Energy and Air Pollution: World Energy. Outlook Special Report pp. 266.

2. (2016) World Energy Council World Energy Resources pp.1028.

3. (2016) Food and Agriculture Organization of The United Nations FAO, State of the World's Forests- Forests and agriculture: land-use challenges and opportunities. Rome, Italy, pp. 126.

4. Bustamante JM, Stevanov M, Krott M, Carvalho EF (2018) Brazilian State Forest Institutions: Implementation of forestry goals evaluated by the 3L Model. Land use policy 79: 531-546.

5. Lubwam M, Yiga VA (2018) Characteristics of briquettes developed from rice and coffee husks for domestic cooking applications in Uganda. Renewable energy 118: 43-55.

6. Blottnitz HV, Curran MA (2007) A review of assessments conducted on bio-ethanol as a transportation fuel from a net energy, greenhouse gas, and environmental life cycle perspective. Journal of cleaner production 15(7): 607-619.

7. Demirbas A (2009) Political, economic and environmental impacts of biofuels: A review. Applied energy 86(1): S108-S117.

\section{Your next submission with Juniper Publishers} will reach you the below assets

- Quality Editorial service

- Swift Peer Review

- Reprints availability

- E-prints Service

- Manuscript Podcast for convenient understanding

- Global attainment for your research

- Manuscript accessibility in different formats

( Pdf, E-pub, Full Text, Audio)

- Unceasing customer service

Track the below URL for one-step submission

https://juniperpublishers.com/online-submission.php 